\title{
High-Penetration, Grid-Connected Photovoltaic Technology Codes and Standards
}

Conference Paper NREL/CP-581-43299

May 2008

\section{Preprint}

T.S. Basso

National Renewable Energy Laboratory

Presented at the 33rd IEEE Photovoltaic Specialists Conference San Diego, California

May 11-16, 2008
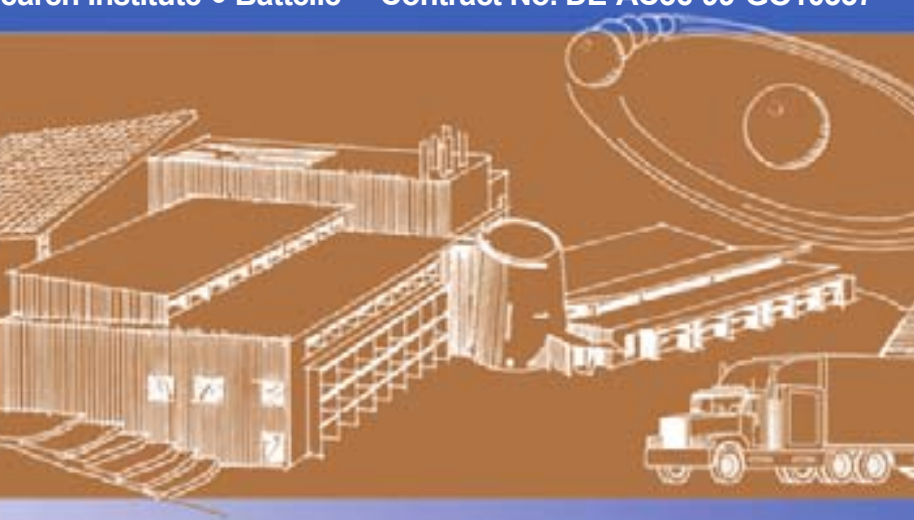


\section{NOTICE}

The submitted manuscript has been offered by an employee of the Midwest Research Institute (MRI), a contractor of the US Government under Contract No. DE-AC36-99G010337. Accordingly, the US Government and MRI retain a nonexclusive royalty-free license to publish or reproduce the published form of this contribution, or allow others to do so, for US Government purposes.

This report was prepared as an account of work sponsored by an agency of the United States government. Neither the United States government nor any agency thereof, nor any of their employees, makes any warranty, express or implied, or assumes any legal liability or responsibility for the accuracy, completeness, or usefulness of any information, apparatus, product, or process disclosed, or represents that its use would not infringe privately owned rights. Reference herein to any specific commercial product, process, or service by trade name, trademark, manufacturer, or otherwise does not necessarily constitute or imply its endorsement, recommendation, or favoring by the United States government or any agency thereof. The views and opinions of authors expressed herein do not necessarily state or reflect those of the United States government or any agency thereof.

Available electronically at http://www.osti.gov/bridge

Available for a processing fee to U.S. Department of Energy and its contractors, in paper, from:

U.S. Department of Energy

Office of Scientific and Technical Information

P.O. Box 62

Oak Ridge, TN 37831-0062

phone: 865.576 .8401

fax: 865.576 .5728

email: mailto:reports@adonis.osti.gov

Available for sale to the public, in paper, from:

U.S. Department of Commerce

National Technical Information Service

5285 Port Royal Road

Springfield, VA 22161

phone: 800.553 .6847

fax: 703.605.6900

email: orders@ntis.fedworld.gov

online ordering: http://www.ntis.gov/ordering.htm 


\title{
HIGH-PENETRATION, GRID-CONNECTED PHOTOVOLTAIC TECHNOLOGY CODES AND STANDARDS
}

\author{
Thomas S. Basso, Senior Engineer \\ National Renewable Energy Laboratory, Golden CO 80401
}

\begin{abstract}
This paper reports the interim status in identifying and reviewing photovoltaic (PV) codes and standards (C\&S) and related electrical activities for grid-connected, highpenetration PV systems with a focus on U.S. electric utility distribution grid interconnection. That includes identifying topics and concerns not yet in the scope of existing C\&S documents, identifying C\&S-related ongoing work and approaches, and providing recommendations related to C\&S needs. This paper also addresses certain technical concerns, e.g., monitoring, information exchange, and control pertaining to business models, tariffs, and economics governed by policy and regulatory mandates. However, the policy, regulatory, and business concerns are not this paper's direct focus. Rather, the primary focus is on systems engineering-based C\&S technical concerns for highpenetration PV systems in U.S. utility distribution grids.
\end{abstract}

\section{INTRODUCTION}

The U.S. electricity grid infrastructure is governed by linked product standards, installation codes, and regulatory functions such as inspection and operation principles. The National Electrical Code, Institute of Electrical and Electronic Engineers, American National Standards, building codes, and state and federal regulatory compliance mandates have worked hand in hand over the past one hundred years, providing us with a safe, reliable, and robust electricity grid. During that period, the electric infrastructure was largely served by vertically integrated entities. The infrastructure grew primarily based on large central-station generating units providing electricity through transmission lines and then through distribution grids that were nominally one-way power flow to customers. Now, deregulation, climate change concerns, renewable portfolio standards, technology cost reductions, coupled with the development of power electronics integrated with information technology advances are promoting unprecedented deployment of distributed PV systems embedded in U.S. electric distribution grids.

Effectively interconnecting high-level penetration of PV systems requires careful technical attention to ensuring compatibility with the existing grid. In the past, the electric grid was not traditionally designed for embedded power sources and two-way flow of power, especially at the distribution level. However, low penetration of small PV systems in itself was not a show stopper for deploying PV systems, especially in relation to energy flow, system protection and coordination, voltage regulation, and power quality. Also, in the past, utilities cared little about monitoring, information exchange, and control (MIC) for low-level penetration of small PV systems. However, for high penetration and larger systems, the utility desire is for significant MIC requirements. And with the opportunity for PV systems qualifying for renewable energy credits, MIC requirements are becoming necessary to validate those credits. But MIC requirements for $\mathrm{PV}$ could be expensive, and PV MIC systems could possibly be noninteroperable, especially with utility legacy data systems.

Currently, interconnection C\&S in the United State have been developed based on passive participation of PV systems in the grid. As higher levels of PV systems are integrated into the electric power system, these PV systems could play an active role in both the technical and business operations of the utility grid and in the customer facility and loads management. C\&S and standardized operating principles will need to be established or reviewed and adjusted to account for that.

Some institutional and business model practices and requirements interfere with, or even prevent, higherpenetration installation of PV systems. Examples include unwarranted interconnection system feasibility and system impact studies, outdated tariff and electricity rate pricing structures, and traditional/outdated business models and practices. Several examples follow: (i) customers attempting to interconnect may be required to pay for pre-interconnection engineering studies, e.g., based on lack of accepted standard approaches; (ii) tariff and rate designs that do not account for grid benefits or services attributed to interconnected PV, or outdated standby, backup, or exit charges; and, (iii) existing business practice and business models based on the old regulated electricity industry dominated by vertically integrated utilities and central-station power plants. Updated or new C\&S are needed to capture the values of non-utility-owned electricity sources, especially on the distribution grid, e.g., delaying or avoiding grid system upgrades; and, accounting for the use of PV providing ancillary services and for improving grid system reliability, power quality, and reducing line losses. In modern competitive electricity markets, business models need to account for the high penetration of PV and equitably realize PV's fair economic value of high-penetration PV. 


\section{INTERCONNECTION CODES AND STANDARDS}

A handful of various local, national, and standards development organization entities and activities have been addressing codes and standards for distributed electric generator integration and interconnection with the utilities. The following identifies the existing codes and standards applicable to high-penetration PV. The 2005 Energy Policy Act (EPACT) cited and mandated the consideration of the Institute of Electrical and Electronic Engineers (IEEE) 1547 standards, and best practices for implementation. Such uniform requirements in the form of the IEEE Std 1547 [1] requirements for power quality, response to abnormal conditions, islanding protection, passive system participation, and the testing procedures in IEEE Std 1547.1 [2] have proven to be a cornerstone for interconnecting all distributed generator to the distribution grid. The Underwriters Laboratories standard UL 1741 (2005) Inverters, Converters, Controllers and Interconnection System Equipment for Use with Distributed Energy Resources [3] scope states that for utility-connected systems, UL 1741 supplements and is intended to be used in conjunction with IEEE Std 1547 and IEEE Std 1547.1. And UL1741 goes beyond 1547 requirements to include product-safety aspects such as construction, materials, wiring, component spacing, and rating, marking, and specific additional tests for various technologies, including PV, wind, microturbines, and fuel cells. For many U.S. locations, the National Electrical Code (NEC) [4] is legislated by state jurisdictions as the governing electrical code that must be adhered to. The NEC includes various requirements specific to $\mathrm{PV}$ and interconnection to the utility such as Article 690 PV Systems, and the Article 705 requirement that interconnection systems shall be suitable per their intended use and identifying compliance to UL1741 as satisfying this NEC requirement. These preceding codes and standards are the specific documents directly applicable to gridconnected PV.

Currently in the United States, there are no national standards at the distribution grid level that universally satisfy utilities for their site-specific, operational, and facility requirements for grid connection. At the transmission level, the North American Electric Reliability Corporation (NERC) mandates that transmission organizations shall assure that any distributed generators connected to NERC jurisdictional transmission facilities satisfy the applicable NERC standards. The NERC mission is to ensure the reliability of the bulk power system in North America, is a self-regulatory organization, and subject to oversight by the U.S. Federal Energy Regulatory Commission and governmental authorities in Canada.

\section{CODES AND STANDARDS CONCERNS AND NEEDS}

Codes, standards, and implementation have been cited as a major impediment to widespread use of PV on the grid in the United States. The IEEE 1547 standard currently addresses requirements primarily for the point of common coupling where the customer electrical facilities connect to the local utility. The IEEE 1547 standard focuses on the technical specifications for, and testing of, the interconnection itself. It is beyond the scope of that standard to address the methods used for performing electric power system impact studies, mitigating limitations of the utility, or for addressing the business or tariff issues associated with interconnection. The technologies and operational concepts to properly integrate distributed resources into the existing utility grid continue to be further developed to fully realize benefits and to avoid negative impacts on system reliability and safety. With IEEE 1547 being a series of standards, additional IEEE 1547 documents are under way to address certain additional topics related to interconnection. Additionally, stakeholders may contact the author to consider developing additional standards related to PV and interconnection. And for the UL 1741 and the NEC, those documents are reviewed and updated periodically, as appropriate, such as to consider new technologies or practices.

The U.S. Department of Energy launched the Renewable Systems Interconnection (RSI) study during the spring of 2007 to facilitate more extensive adoption of renewable distributed electricity generation, This study addressed the technical and analytical challenges to enable high penetration levels of distributed renewable energy technologies. Because integrationrelated issues at the distribution system are likely to emerge first for PV technology, the RSI study focused on this area. A key goal of the RSI study was to identify the research and development needed to build the foundation for a high-penetration renewable energy future while enhancing the operation of the electricity grid. The RSI study consists of 15 reports that address a variety of issues related to distributed systems technology development; advanced distribution systems integration; system-level tests and demonstrations; technical and market analysis; resource assessment; and codes, standards, and regulatory implementation [5]. There is no dedicated report on codes and standards, but the C\&S concerns and needs are interspersed in the reports for appropriate organizations developing standards to consider.

The following identifies a number of technical concerns and issues that would be appropriate for potential C\&S development. For high-penetration and large PV (and wind energy systems) connected at bulk or high-voltage level, issues include the following: steady-state and transient stability analysis; load/generation coincidence (peak load and variability of source); regulation requirements (transmission/bulk level); integration with automatic generation control (AGC); incorporation of renewable resource forecasting; examination of current operating practice and new concepts to enable high penetration; frequency responsiveness (create regulating reserves); and demand-side coordination. 
Primarily, the bulk-level connection concerns relate to the need for better understanding how to plan and operate the transmission grid and other generation resources based on renewable energy operating characteristics. For high-penetration PV (and small wind systems) at the distribution level, the issues include those listed above plus: voltage and reactive power regulation; power quality (harmonics, flicker, DC injection); protection design and coordination (e.g., short circuits, re-closers, fuses); unintentional islanding; equipment grounding; load and generation imbalance (e.g., generation interaction with controllable loadsdemand-side management); and storage and storage controls. The distribution-level connection issues primarily relate to feeder-level issues such as power flows, protection, and voltage impacts. However daunting these lists may seem, dedicated professionals know how to resolve these. But it is generally necessary to pursue that on a case-by-case basis, which is time and resource intensive. Codes and standards would greatly help realize the transparent and cost-effective deployment for high-penetration PV.

In the RSI study's Executive Summary [4] report, the codes and standards recommendations are stated as follows:

- Enable coordinated operation of all equipment on the distribution feeder. (The same infrastructure then enables demand-side management, implements flexible metering tariffs, and enhances distribution system management.)

- Establish recommended practices for modeling highpenetration, intermittent renewable energy power sources and energy storage systems embedded in the distribution system.

- Develop consensus best practices that facilitate transmission and distribution (T\&D) system planning and operation for grid modernization, which includes provision for greater deployment of renewable energy systems.

- Develop recommendations for electricity regulators to consider on net metering and rate structures, microgrids, and impact study requirements.

- Improve methods and agreements for local siting, permitting, and inspection of PV systems.

\section{CONCLUSION}

The individual standards development organizations would thus need to consider the preceding RSI C\&S concerns and needs, and recommendations toward establishing new or updated codes and standards. In addition to the RSI study C\&S recommendations, the following venues-Solar America Board for Codes and Standards (Solar ABCs) and Smart Grid Interoperability Framework-provide C\&S approaches, insight, and recommendations for helping to accelerate the realization of high-penetration $\mathrm{PV}$.

The U.S. Department of Energy's Solar America Initiative for Market Transformation resulted in establishing the Solar ABCs in mid-2007 (www.SolarABCs.org). The mission of the Solar ABCs includes improving the responsiveness, effectiveness, and accessibility of codes and standards. The Solar $A B C$ s has conducted an initial codes and standards gap analysis, and that information should be publicly available in the near future.

Another federal act that is synergistic to highpenetration, grid-connected PV and directly related to codes and standards is the Energy Independence and Security Act (EISA) 2007. Specifically, Section 1305 Smart Grid Interoperability Framework states: "The Director of the National Institute of Standards and Technology has the primary responsibility to coordinate the development of a framework that includes protocols and model standards for information management to achieve interoperability of smart grid devices and systems. Such protocols and standards shall further align policy, business, and technology approaches in a manner that would enable all electric resources, including demand-side resources, to contribute to an efficient, reliable electricity network." Further, that section states "the $\{$ NIST\} Director shall also solicit input and cooperation from private entities interested in such protocols and standards, including but not limited to the Gridwise Architecture Council, the Institute of Electrical and Electronics Engineers, the North America Electric Reliability Corporation recognized by the Federal Energy Regulatory Commission, and National Electrical Manufacturer's Association." On behalf of IEEE, the IEEE Standards Board appointed Richard DeBlasio as point of contact for IEEE standards for the NIST Team developing an interoperability framework, and he will lead IEEE interactions on behalf of the IEEE Standards Association and will coordinate with all IEEE groups developing standards and with the IEEE Standards Board.

Addressing grid-integration technical and analytical issues is a necessary prerequisite for the long-term viability of the distributed renewable energy $P V$ industry, and, in particular, that is paramount for high penetration. Using the R\&D findings and results to establish improved codes and standards will enable an accelerated timeframe for realizing high-penetration, grid-connected PV. With the RSI study being one step on this path-and with additional stakeholders such as those identified in EISA 2007 working on codes and standards activities aimed at interoperability and grid modernization - the deployment of high-penetration PV technology should be realized sooner. 


\section{ACKNOWLEDGEMENTS}

This work was supported by the U.S. Department of Energy under Contract No. DE-AC36-99G010337 with the National Renewable Energy Laboratory.

\section{REFERENCES}

[1] IEEE 1547 (2003), IEEE Standard for Interconnecting Distributed Resources with Electric Power Systems.

[2] IEEE 1547.1 (2005), IEEE Standard Conformance Test Procedures for Equipment Interconnecting

Distributed Resources with Electric Power Systems.

[3] National Fire Protection Association National Electrical Code - NEC (2008).

[4] UL 1741 (2005), Inverters, Converters, Controllers, and Interconnection System Equipment for Use with Distributed Energy Resources.

[5] Renewable Systems Interconnection (RSI) study reports

(www.eere.energy.gov/solar/solar america/rsi.html) 


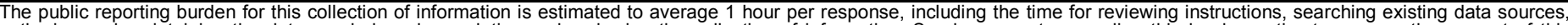

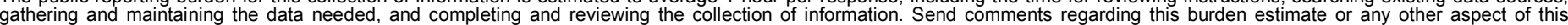

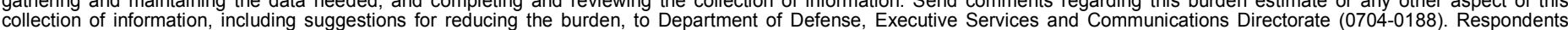

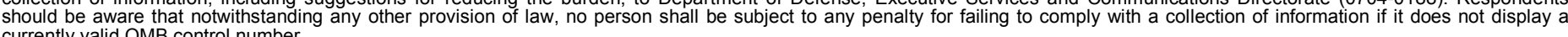

PLEASE DO NOT RETURN YOUR FORM TO THE ABOVE ORGANIZATION.

\section{REPORT DATE (DD-MM-YYYY) May 2008 \\ 2. REPORT TYPE Conference Paper}

4. TITLE AND SUBTITLE

High-Penetration, Grid-Connected Photovoltaic Technology Codes and Standards: Preprint
3. DATES COVERED (From - To)

11-16 May 2008

5a. CONTRACT NUMBER

DE-AC36-99-G010337

5b. GRANT NUMBER

5c. PROGRAM ELEMENT NUMBER

5d. PROJECT NUMBER

NREL/CP-581-43299

5e. TASK NUMBER

PVC78301

5f. WORK UNIT NUMBER

7. PERFORMING ORGANIZATION NAME(S) AND ADDRESS(ES)

National Renewable Energy Laboratory

1617 Cole Blvd

8. PERFORMING ORGANIZATION REPORT NUMBER

Golden, CO 80401-3393

NREL/CP-581-43299

9. SPONSORING/MONITORING AGENCY NAME(S) AND ADDRESS(ES)

10. SPONSOR/MONITOR'S ACRONYM(S) NREL

11. SPONSORING/MONITORING AGENCY REPORT NUMBER

12. DISTRIBUTION AVAILABILITY STATEMENT

National Technical Information Service

U.S. Department of Commerce

5285 Port Royal Road

Springfield, VA 22161

\section{SUPPLEMENTARY NOTES}

14. ABSTRACT (Maximum 200 Words)

This paper reports the interim status in identifying and reviewing photovoltaic (PV) codes and standards (C\&S) and related electrical activities for grid-connected, high-penetration PV systems with a focus on U.S. electric utility distribution grid interconnection. That includes identifying topics and concerns not yet in the scope of existing C\&S documents, identifying C\&S-related ongoing work and approaches, and providing recommendations related to C\&S needs. This paper also addresses certain technical concerns, e.g., monitoring, information exchange, and control pertaining to business models, tariffs, and economics governed by policy and regulatory mandates. However, the policy, regulatory, and business concerns are not this paper's direct focus. Rather, the primary focus is on systems engineering-based C\&S technical concerns for high-penetration PV systems in U.S. utility distribution grids.

15. SUBJECT TERMS

PV; high- penetration PV systems; grid integration; codes and standards; utility distribution grid; renewable systems interconnection;

\begin{tabular}{|l|l|l|l|l|}
\hline \multicolumn{2}{|l|}{ 16. SECURITY CLASSIFICATION OF: } & $\begin{array}{c}\text { 17. } \\
\text { LIMITATION } \\
\text { OF ABSTRACT }\end{array}$ & $\begin{array}{c}\text { 18. } \\
\text { NUMBER } \\
\text { OF PAGES }\end{array}$ \\
\hline $\begin{array}{l}\text { a. REPORT } \\
\text { Unclassified }\end{array}$ & $\begin{array}{c}\text { b. ABSTRACT } \\
\text { Unclassified }\end{array}$ & $\begin{array}{c}\text { c. THIS PAGE } \\
\text { Unclassified }\end{array}$ & $\begin{array}{c}\text { UL } \\
\end{array}$ &
\end{tabular}

19a. NAME OF RESPONSIBLE PERSON

19b. TELEPHONE NUMBER (Include area code) 